\title{
Improvement of Soil Quality Parameters by Municipal Solid Waste Compost Application in Clay-Loam Soil
}

\author{
Orhan Yüksel,a, ${ }^{1,}$, Yasemin Kavdır²,b \\ ${ }^{1}$ Department of Soil Science and Plant Nutrition, Agricultural Faculty, Tekirda $\breve{g}$ Namık Kemal University, 59030 Tekirdağ, Turkey \\ ${ }^{2}$ Department of Soil Science and Plant Nutrition, Agricultural Faculty, Çanakkale Onsekiz Mart University, 17020 Çanakkale, Turkey \\ *Corresponding author

\begin{tabular}{|c|c|}
\hline A R T I C L I N F O & A B S T R A C T \\
\hline $\begin{array}{l}\text { Keywords: } \\
\text { Waste compost } \\
\text { Soil } \\
\text { Field experiment } \\
\text { Soil characteristics } \\
\text { Organic matter }\end{array}$ & $\begin{array}{l}\text { Organic matter (OM) content of the soils should be improved for sustainable productions. Municipal } \\
\text { solid waste compost (MSWC) is an organic material used in several countries to improve soil OM } \\
\text { contents. This study was conducted to determine potential use of MSWC as soil amendment. Field } \\
\text { experiments were conducted for two years with single MSWC treatments. Experiments were } \\
\text { conducted on } 18 \text { plots in randomized complete blocks design with } 3 \text { replications. Six different } \\
\text { MSWC doses ( } 0,40,80,120,160 \text { and } 200 \mathrm{t} \mathrm{ha}{ }^{-1} \text { ) were applied to experimental plots. Compost doses } \\
\text { were calculated in dry weight basis, applied to } 21 \mathrm{~m}^{2} \text { plots and sunflower was sown as the } \\
\text { experimental plant of the study. Following the sunflower harvest, disturbed and undisturbed soil } \\
\text { samples were taken from the experimental plots and soil samples were subjected to various analyses. } \\
\text { Applied MSWC doses significantly increased soil OM contents, electrical conductivity (EC) and } \\
\text { cation exchange capacity (CEC), aggregate stability (AS) and saturated hydraulic conductivity } \\
\text { (Ksat) and reduced soil bulk density (BD). Effects of MSWC on soil pH were not found to be } \\
\text { significant. Effects of MSWC treatments were more remarkable with increasing doses. MSWC } \\
\text { treatments increased soil OM contents about } 3 \text { folds and increased CEC by about } 25 \% \text {. MSWC } \\
\text { treatments significantly increased salt contents of the soils. Such increases were found to be } \\
\text { significant at } 1 \% \text { level in the first year and } 5 \% \text { level in the second year. Increasing OM contents also } \\
\text { increase soil aggregation, thus reduced bulk density and increased hydraulic conductivity. } \\
\text { Correlation analysis revealed significant correlations between OM and AS. Present findings revealed } \\
\text { that MSWC positively influenced physical and chemical characteristics of clay-loam soils of arid } \\
\text { and arid climates, but salt contents should carefully be monitored in repetitive uses. }\end{array}$ \\
\hline
\end{tabular}

\section{Introduction}

Temperature, insufficient precipitation and excessive soil tillage significantly reduce OM contents of the soils of arid and semi-arid regions. Soil OM quantities should be preserved even should be increased for sustainability of soil fertility. Therefore, soils should regularly be supplemented with organic matters. Various organic wastes are composted and applied to soils widely to improve soil OM contents. Composted organic amendments have various positive impacts on soil physical, chemical and biological characteristics (Westerman and Bicudo, 2005; Hernandez et al., 2015; Kavdir et al., 2020). High organic C contents are the greatest attribute of these organic materials (Erhart and Hartl, 2010). MSWC is an organic material able to be used as an organic source of $\mathrm{C}$ to improve OM contents of the soils over which intensive agriculture is practiced (Annabi, 2007; Hargreaves et al., 2008). MSWC is quite rich in organic carbon and effects of this material on soil characteristics largely depend on compost composition, application doses and maturity level of the compost (Crecchio et al., 2001; Weber et al., 2014).

MSWCs also contain high quantities of nutrients. Therefore, they are most of the time known as organic fertilizers. Despite the high nutrient contents, they primarily improve soil physical characteristics rather than compensating commercial fertilizers (Sanchez et al., 2016). MSWC with high OM content regulates soil structure and increase soil aggregation (Annabi, 2007; Karami et al., 2012), thus increase soil porosity (Hemmat et al., 2010; Eibisch et al., 2015) and reduce BD (Tejada and Gonzalez, 2007; Diacono and Montemurro, 2010). Improved soil structure then positively influences soil Ksat value. Zamani et al. (2016) related the effects of MSWC on soil Ksat to high $\mathrm{OM}$ content. Besides high OM contents, MSWCs also 
contain high quantities of humic acid. There are significant correlations between AS and humic acid (Piccolo et al., 1992; Tejada and Gonzalez, 2007). The materials with high humic acid contents improve soil structure and AS (Karami et al., 2012). Albiach et al. (2001) investigated various organic materials and reported the greatest increases in soil $\mathrm{OM}$ and humic acid contents with MSWC.

Effects of composts on soils largely vary with the application doses and frequencies. Increasing positive impacts of composts on soil characteristics were reported with increasing doses (Yuksel et al., 2004; Karami et al., 2012) and frequencies (Diacono and Montemurro, 2010; Erhart and Hartl, 2010). Several other studies also reported the best achievements with the greatest MSWC doses (Bastida et al., 2007; Karami et al., 2012; Yuksel, 2012). High compost doses result in greater increases in soil organic carbon contents, thus more remarkable impacts on soil characteristics (Weber et al., 2014). Hernandez et al. (2015) indicated that soil water holding capacity, porosity, AS and nutrient contents of compost-treated soils were greater than the control treatments even 5 years after the treatments and such impacts were more remarkable at higher doses. Diacono and Montemurro (2010) indicated that long-term high MSWC doses increased soil organic carbon contents up to $90 \%$. Although researchers applied different compost doses, they mostly recommended regular compost application of 6-7 $\mathrm{t} \mathrm{ha}^{-1} \mathrm{year}^{-1}$ for sustainable OM content in soils (Erhart and Hartl, 2010).

MSWCs have various positive impacts also on soil chemical characteristics. Parallel to increasing OM contents, MSWC also increase CEC and nutrient contents of the soils. The $\mathrm{pH}$ of low-pH soils increases, thus heavy metal uptake of the plants is restricted. MSWC may have some negative impacts on agricultural fields since these composts have high heavy metal and salt contents (Alvarenga et al., 2015). It was reported in previous studies that MSWC treatments increased soil heavy metal and salt contents, but such increased values were still within the limit values (Hernandez et al., 2015; Yuksel, 2015). MSWCs have quite low risk of heavy metal accumulation in soils when the legal standards are obeyed strictly (Erhart and Hartl, 2010).

Just because of arid and semi-arid climate conditions and high water erosions, Turkish soils generally have low OM contents. Therefore, soils should regularly be supplemented with organic matters. However, OM sources are quite limited. MSWC then becomes the primary source of OM for soils. But, production and agricultural use of MSWC is quite limited in Turkey. According to 2016 data, in Turkey, 140.467 tons municipal waste were composted in 7 municipal composting facilities with a total capacity of 424.000 t year $^{-1}$ and 20.000 ton compost were produced (TUIK, 2017).

This study was conducted to point out the significance of MSWC for soils. The primary objective was to prove that MSWC was a well organic soil amendment improving soil chemical and physical characteristics and to encourage the use of MSWC for agricultural purposes in Turkey. Produced compost mostly used in fertilization of municipal parks and landscapes and only small quantities are used for agricultural purposes (ISTAC, 2017). Besides encouraging MSWC use in agricultural fields, the inconvenient or unfavorable issues were also pointed out.

\section{Materials and Methods}

\section{Experimental Soil and Waste Compost}

Experiments were conducted at Dardanos experimental fields of Çanakkale Onsekiz Mart University (ÇanakkaleTurkey) (4004'16.64'’N; 26²1'49.67' E) (Figure 1). Experimental soils were classified in Fluventic Haploxerepts soils. Soils were composed of alluvial deposits at different depths and lime content was high. Except for the bottom layer, soil texture is clay-loam. The upper horizon (Ap) has a depth of $0-17 \mathrm{~cm}$ and has a granular structure. Soils are quite hard when they are dry and sticky and plastic when they are wet (Ozcan et al., 2004). Some physical and chemical characteristic of the soils are provided in Table 1.

The MSWC used in experiments was supplied from Uzundere Composting Facility of Izmir Metropolitan Municipality. MSWC was produced from non-source separated municipal wastes. Some characteristics of the MSWC are provided in Table 2.

Marmara Region climate is dominant in research site. It is a transitional climate between Mediterranean and Black Sea climates. Entire year is precipitated especially in spring and autumn, winters are cold and summers are hot. Annual average precipitation is $600 \mathrm{~mm}$, relative humidity is $78 \%$ and temperature is $14.9^{\circ} \mathrm{C}$ (Ozcan et al., 2004).

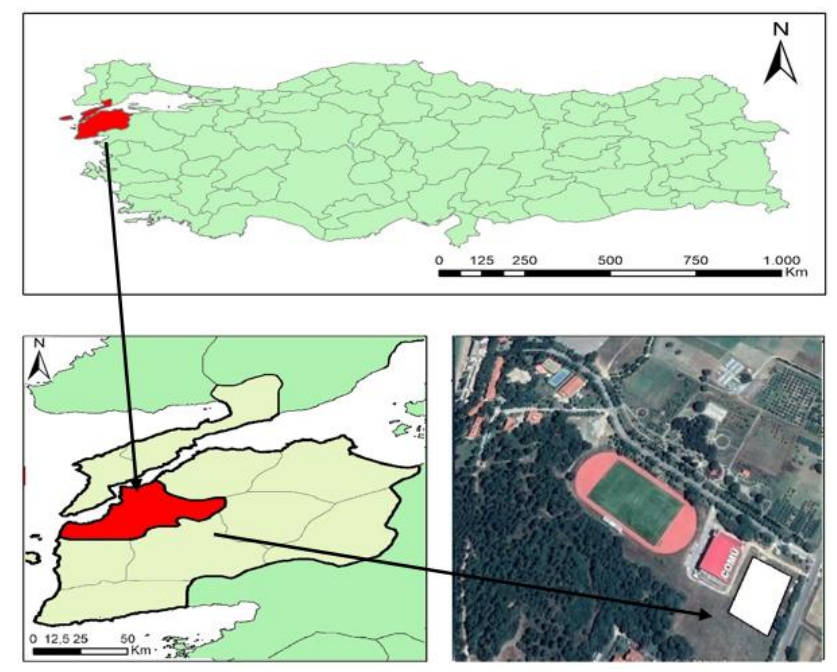

Figure 1. Location of the study area

\section{Field Trial}

Field experiments were conducted for 2 years in completely randomized blocks design with 3 replications on 18 plots. Six different compost doses $(0,40,80,120$, 160 and $200 \mathrm{t} \mathrm{ha}^{-1}$ ) were experimented in this study. The amounts of MSWC to be applied to experimental plots were calculated in dry weight basis following the moisture content analyses. Sunflower seeds were sown (at $70 \times 30 \mathrm{~cm}$ spacing) in $21 \mathrm{~m}^{2}(4.2 \times 5 \mathrm{~m})$ plots. About 1 month after MSWC treatments, sunflower (cv. Sanbro, Syngenta Seed Company) seeds were sown at $70 \mathrm{~cm}$ row spacing and 30 $\mathrm{cm}$ on-row plant spacing. Chemicals or fertilizers were not applied to plots until the harvest of the sunflowers (Yuksel et al., 2011). Following the harvest, disturbed and undisturbed soil samples were taken from the experimental plots. To see the effects of compost treatments in the $2^{\text {nd }}$ 
year, MSWC was not applied again in the second year. Plots were tilled and second sunflower sowing was performed. Disturbed and undisturbed soil samples were again taken at the end of the second year. Disturbed soil samples were taken with a shovel from $0-20 \mathrm{~cm}$ soil profile and undisturbed samples were taken into $100 \mathrm{~cm}^{3}$ sampling tubes. Disturbed samples were dried at room temperature and passed through $2 \mathrm{~mm}$ sieve. These samples were then used for $\mathrm{OM}, \mathrm{pH}$, electrical conductivity (EC), cation exchange capacity (CEC), particle size distribution (texture) and AS analyses. Undisturbed soil samples were used for BD and Ksat analyses.

\section{Analyses Methods}

OM contents of the soil samples were determined in accordance with Smith-Weldon method (Nelson and Sommers, 1996), $\mathrm{pH}$ was determined in 1:2.5 soil:water suspension with a $\mathrm{pH}$-meter, EC was determined in 1:2.5 soil:water suspension with an EC-meter (Soil Survey Staff, 1996), $\mathrm{CaCO}_{3}$ contents were measured with a calcimeter (Loeppert and Suarez, 1996), CEC's were determined by ammonium acetate (pH: 7) method (Sumner and Miller, 1996), total Na, K, Ca contents of the soil samples were determined by wet-digestion in $1: 3 \mathrm{HNO}_{3}: \mathrm{HCl}$ mixture using inductively coupled plasma atomic emission spectroscopy (ICP-OES) device (Spectro Arcos).
Total OM of the waste compost was determined through ashing at $650^{\circ} \mathrm{C}$ for $3 \mathrm{~h}$ and by using the remaining ash (LOI method) (Sutherland, 1998); EC was measured from 1:5 compost-water (distilled) suspension with an EC meter; $\mathrm{pH}$ was determined in 1:3 compost $-1 \mathrm{~N} \mathrm{KCl}$ suspension with a pH-meter; $\mathrm{CaCO}_{3}$ was determined by using calcimeter method (EAWAG, 1970). Total macro-elements of waste compost $(\mathrm{Ca}, \mathrm{Mg}, \mathrm{K}, \mathrm{Na}$ and $\mathrm{P}$ ) were determined through wet-digestion in $\mathrm{HCl}$ and $\mathrm{HNO}_{3}$ (3:1 ratio) and determined Inductively Coupled Plasma Atomic Emission Spectroscopy (ICP-OES) device (Spectro Arcos).

Soil bulk density analyses were carried out on $100 \mathrm{~cm}^{3}$ undisturbed samples by using core method (Blake and Hartge, 1986). Saturated hydraulic conductivity was determined by using constant head method (Klute and Dirksen, 1996). Soil aggregate stability (on 1-2 mm aggregates) was determined by using wet-sieving apparatus in accordance with the principles specified by Kemper and Rosenau (1986). Soil texture was determined with the hydrometer method (Gee and Bauder, 1986).

\section{Data Analysis}

Experimental data were subjected to variance analysis with TARIST statistical software in accordance with randomized blocks design. Means were compared with LSD test $(\mathrm{P} \leq 0.05)$ (Steel and Torrie, 1960).

Table 1. Physical and chemical soil characteristics of the experimental site

\begin{tabular}{|c|c|c|c|c|c|c|c|c|c|}
\hline \multirow{2}{*}{$\begin{array}{l}\text { O.M } \\
(\%)\end{array}$} & \multirow{2}{*}{$\mathrm{pH}$} & \multirow{2}{*}{ 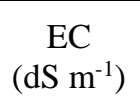 } & \multirow{2}{*}{$\begin{array}{c}\mathrm{CaCO}_{3} \\
(\%)\end{array}$} & \multirow{2}{*}{$\begin{array}{c}\mathrm{CEC} \\
\left(\mathrm{c} \mathrm{mol} \mathrm{kg}{ }^{-1}\right)\end{array}$} & $\mathrm{Na}$ & $\mathrm{K}$ & $\mathrm{Ca}$ & \multirow{2}{*}{$\begin{array}{c}\mathrm{BD} \\
\left(\mathrm{g} \mathrm{cm}^{-3}\right)\end{array}$} & \multirow{2}{*}{$\begin{array}{c}\text { Texture } \\
\text { Class }\end{array}$} \\
\hline & & & & & & $\mathrm{kg}^{-1}$ & & & \\
\hline 1.40 & 7.50 & 0.064 & 11.5 & 21.27 & 0.62 & 5.62 & 38.15 & 1.46 & CL \\
\hline
\end{tabular}

Table 2. Chemical characteristics of MSWC used in the experiment

\begin{tabular}{c|cccccccc}
\hline $\begin{array}{c}\mathrm{O} . \mathrm{M} \\
(\%)\end{array}$ & $\mathrm{pH}$ & $\begin{array}{c}\mathrm{EC} \\
\left.(\mathrm{dS} \mathrm{m})^{-1}\right)\end{array}$ & $\begin{array}{c}\mathrm{CaCO}_{3} \\
(\%)\end{array}$ & $\mathrm{Ca}$ & $\mathrm{Mg}$ & $\mathrm{K}$ & $\mathrm{Na}$ & $\mathrm{P}$ \\
\hline 32.2 & 7.68 & 3.75 & 13.8 & 55 & 2.9 & 12.8 & 5.9 & 2.1 \\
\hline
\end{tabular}

OM: Organic matter, EC: Electrical conductivity $\left(\mathrm{dS} \mathrm{m}^{-1}\right)$

\section{Results and Discussion}

\section{Soil Chemical Properties}

OM content of the soils treated with different doses of MSWC significantly increased in both years $(\mathrm{P} \leq 0.01)$. Increases in soil OM contents were parallel to compost doses and increasing OM contents were observed with increasing compost doses. The greatest increase in OM contents was obtained from $200 \mathrm{t} \mathrm{ha}^{-1}$ compost treatment. The OM content of $1.37 \%$ in the first year and $1.42 \%$ in the second year of the control treatment increased with $200 \mathrm{t}$ $\mathrm{ha}^{-1}$ treatments respectively to $4.05 \%$ and $3.76 \%$ (Table 3 ). Present MSWC with high OM content increased soil OM content. Previous researchers also indicated high OM contents of MSWC and thus reported significant increases in soil OM contents with MSWC treatments (Pedra et al., 2007; Weber et al., 2014; Füleky and Benedek, 2010). Bastida et al. (2007) reported that soil OM contents increased with the greatest dose of $\operatorname{MSWC}\left(260 \mathrm{Mg} \mathrm{ha}^{-1}\right)$ from $4.30 \mathrm{~g} \mathrm{~kg}^{-1}$ to $12.0 \mathrm{~g} \mathrm{~kg}^{-1}$. Similarly, Albiach et al. (2001) applied different organic materials to the soils and reported the greatest OM contents for MSWC-treated soils.
Diacono and Montemurro (2010) reported that soil organic C contents increased with long-term organic amendment treatments by about $90 \%$ as compared to non-fertilized soils and by $100 \%$ as compared to the chemical fertilizers.

OM contents of the experimental soils slightly decreased in the second year with the effect of decomposition, but the values were close to each other in both years. Such a case indicated that effects of MSWC were largely sustained also in the second year. Such a sustained effect of MSWC can be attributed to initial low nitrogen, $\mathrm{pH}$ and high oil content and thus slowed down microorganism activity and late decomposition of the compost (Atagana et al., 2003; Neves et al., 2009). Weber et al. (2007) indicated that effect of MSWC on soil OM content lasted for at least 3 years.

The effects of MSW compost on soil $\mathrm{pH}$ were not significant (Table 3 ). The $\mathrm{pH}$ values of the compost-treated and untreated soils were close to each other. Therefore, the $\mathrm{pH}$ values did not change significantly with the compost treatments. Previous researchers also indicated that MSWC did not have significant effects on $\mathrm{pH}$ of soils with 
relatively high initial $\mathrm{pH}$ values. Carbonell et al. (2011) indicated that $50 \mathrm{Mg} \mathrm{ha}^{-1} \mathrm{MSWC}$ treatments did not have significant effects on $\mathrm{pH}$ of loamy-sand soils with initial $\mathrm{pH}$ of 8.42. However, some other researchers reported that MSWC treatments significantly increased $\mathrm{pH}$ of soils with low initial $\mathrm{pH}$ values. Zheljazkov and Warman (2004) carried out experiments with two different plants and reported that MSWC treatments increased $\mathrm{pH}$ values of 5.33 and 5.99 in control treatments to 6.56 and 6.61 . Similarly, Zhang et al. (2006) carried out experiments at two different locations and reported that $\mathrm{pH}$ values of 5.8 and 6.0 in control treatments increased with $200 \mathrm{t} \mathrm{ha}^{-1}$ MSWC respectively to 6.7 and 6.5 .

Soil EC value of $0.068 \mathrm{dS} \mathrm{m}^{-1}$ in the control treatment of the first year increased with the greatest compost dose $\left(200 \mathrm{t} \mathrm{ha}^{-1}\right.$ ) to $0.361 \mathrm{dS} \mathrm{m}^{-1}$. In the second year, the values decreased, but still increased in all treatments as compared to the control treatments. The EC value of $0.039 \mathrm{dS} \mathrm{m}^{-1}$ in the control treatment of the second year increase with $16 \mathrm{t}$ $\mathrm{ha}^{-1}$ dose to $0.095 \mathrm{dS} \mathrm{m}^{-1}$ (Table 3). Such increases were found to be significant at $1 \%$ level in the first year and $5 \%$ level in the second year. Present findings revealed that effects of MSWC on soil EC also sustained in the second year even with slight decreases. Salt leaching through precipitations may be considered as the primary reason of decreasing EC values (Mylavarapu and Zinati, 2009). Hicklenton et al. (2001) experimented different organic materials and reported the greatest EC value for MSWC treatments and also reported decreasing EC values in time. Hernandez et al. (2015) indicated that MSWC treatments, especially at higher doses, increased soil EC values. In present study, although increasing MSWC doses increased soil EC values, present EC values did not reach to critical levels even with the greatest dose. Hamidpour et al. (2012) reported that MSWC treatments increased soil EC values, but never exceeded critical values for wheat plants.

Cation exchange capacity (CEC) is a significant soil chemical characteristic and present values significantly increased in both years with MSWC treatments $(\mathrm{P} \leq 0.01)$. CEC values increased with increasing MSWC doses and the greatest CEC values were observed in $200 \mathrm{t} \mathrm{ha}^{-1}$ compost dose. CEC values increased from $21.27 \mathrm{cmol} \mathrm{kg}^{-1}$ to $26.64 \mathrm{cmol} \mathrm{kg}^{-1}$ in the first year and from $22.04 \mathrm{cmol} \mathrm{kg}^{-1}$ to $27.11 \mathrm{cmol} \mathrm{kg}^{-1}$ in the second year (Table 3). MSWCs have high OM contents, thus they increase soil CEC values (Gallardo-Lara and Nogales 1987). There is a close relationship between OM and CEC. CEC increases with increasing OM contents (Loveland and Webb 2003).
Amlinger et al. (2007) indicated that OM increased soil CEC values by about 20-70\% and Hemmat et al. (2010) indicated that OM increased soil CEC values by about 25$90 \%$.

\section{Soil Physical Properties}

MSWC treatments at different doses decreased soil bulk density (BD) in both years. Significant decreases were observed in all treatments as compared to the control treatments. The greatest decrease was observed in $160 \mathrm{t} \mathrm{ha}^{-1}$ dose in the first year and in $120 \mathrm{tha}^{-1}$ and $200 \mathrm{t} \mathrm{ha}^{-1}$ compost treatments in the second year. While the effects of compost treatments on soil BD were found to be significant in the first year $(\mathrm{P} \leq 0.05)$, the effects were not found to be significant in the second year (Table 4). Previous researchers also reported decreasing soil BD with MSWC treatments (Zamani et al., 2016; Civeira, 2010). Such decreases mostly attributed to high OM content of MSWC. According to Diacono and Montemurro (2010), regular composted organic waste treatments primarily improved AS and decreased BD, thus improved soil physical fertility. Decreasing BD values with MSWC treatments were also attributed to better aggregation with OM treatments, thus increased porosity (Hemmat et al., 2010; Eibisch et al., 2015) and decreased weight of mixture with low-density OM (Maylavarapu and Zinati, 2009).

Previous researchers also indicated that $\mathrm{OM}$ supplementation regulated soil aggregation and increased AS (Karami et al., 2012; Leroy et al., 2008). Kavdir and Killi (2008) indicated that olive oil solid waste treatments with high OM contents significantly increased AS of clayloam soils. In present study, MSWC with high OM content also increased soil AS. Such increases were more remarkable at higher doses and were found to be significant in both years $(\mathrm{P} \leq 0.01)$. The AS of $51.61 \%$ in control treatment of the first year increased with $20 \mathrm{tha}^{-1}$ compost dose to $57.02 \%$. The AS of $52.27 \%$ in control treatment of the second year increased with $16 \mathrm{t} \mathrm{ha}^{-1}$ dose to $60.88 \%$ (Table 4). Previous researchers also reported increased AS with waste compost treatments (Annabi, 2007; Bastida et al., 2007). Positive impacts of MSWC on AS can be attributed to high humic acid content of MSWC. Albiach et al. (2001) carried out a study with 5 different organic amendments and indicated MSWC as the best source of humic acid. Hernandez et al. (2015) reported that MSWC treatments increased soil humic acid contents and such increases were more remarkable at higher doses.

Table 3. Effects of MSWC applications on soil chemical properties.

\begin{tabular}{l|cccccccc}
\hline \multirow{2}{*}{$\begin{array}{c}\text { Soil } \\
\text { Properties }\end{array}$} & \multirow{2}{*}{ Year } & & \multicolumn{7}{c}{ Compost Dose $\left(\mathrm{t} \mathrm{ha}{ }^{-1}\right)$} \\
\cline { 2 - 9 } & & 0 & 40 & 80 & 120 & 160 & 200 & LSD $_{0.05}$ \\
\hline Organic & 1 & $1.37^{\mathrm{d}}$ & $2.12^{\mathrm{c}}$ & $2.37^{\mathrm{c}}$ & $2.55^{\mathrm{c}}$ & $3.55^{\mathrm{b}}$ & $4.05^{\mathrm{a}}$ & $0.46^{* *}$ \\
Matter $(\%)$ & 2 & $1.42^{\mathrm{c}}$ & $2.21^{\mathrm{b}}$ & $2.34^{\mathrm{b}}$ & $2.63^{\mathrm{b}}$ & $3.32^{\mathrm{a}}$ & $3.76^{\mathrm{a}}$ & $0.64^{* *}$ \\
\hline \multirow{2}{*}{$\mathrm{pH}$} & 1 & 7.50 & 7.51 & 7.57 & 7.49 & 7.46 & 7.52 & $\mathrm{~ns}$ \\
& 2 & 7.68 & 7.59 & 7.57 & 7.67 & 7.57 & 7.46 & $\mathrm{~ns}$ \\
\hline $\mathrm{EC}$ & 1 & $0.068^{\mathrm{e}}$ & $0.129^{\mathrm{de}}$ & $0.175^{\mathrm{cd}}$ & $0.239^{\mathrm{bc}}$ & $0.342^{\mathrm{ab}}$ & $0.361^{\mathrm{a}}$ & $0.105^{* *}$ \\
$\left(\mathrm{dS} \mathrm{m}{ }^{-1}\right)$ & 2 & $0.040^{\mathrm{f}}$ & $0.054^{\mathrm{e}}$ & $0.066^{\mathrm{c}}$ & $0.062^{\mathrm{d}}$ & $0.095^{\mathrm{a}}$ & $0.084^{\mathrm{b}}$ & $0.004^{*}$ \\
\hline $\mathrm{CEC}$ & 1 & $21.27^{\mathrm{e}}$ & $22.13^{\mathrm{de}}$ & $22.41^{\mathrm{d}}$ & $24.54^{\mathrm{c}}$ & $25.65^{\mathrm{b}}$ & $26.64^{\mathrm{a}}$ & $0.95^{* *}$ \\
$\left(\mathrm{cmol} \mathrm{kg}{ }^{-1}\right)$ & 2 & $22.04^{\mathrm{d}}$ & $23.41^{\mathrm{c}}$ & $23.84^{\mathrm{c}}$ & $25.19^{\mathrm{b}}$ & $25.93^{\mathrm{b}}$ & $27.11^{\mathrm{a}}$ & $0.95^{* *}$ \\
\hline
\end{tabular}

${ }^{*}:$ Means with the same letter for each parameter are significantly different $(\mathrm{P}=0.05),{ }^{* *}$ : Means with the same letter for each parameter are significantly different $(\mathrm{P}=0.01)$, ns: not significant 
Table 4. Effects of MSWC applications on soil physical properties

\begin{tabular}{l|cccccccc}
\hline \multirow{2}{*}{ Soil properties } & \multirow{2}{*}{ Years } & \multicolumn{7}{c}{ Compost Dose $\left(\mathrm{t} \mathrm{ha}^{-1}\right)$} \\
\cline { 2 - 8 } & & 0 & 40 & 80 & 120 & 160 & 200 & LSD $_{0.05}$ \\
\hline Bulk density & 1 & $1.46^{\mathrm{a}}$ & $1.39^{\mathrm{ab}}$ & $1.37^{\mathrm{abc}}$ & $1.30^{\mathrm{bc}}$ & $1.29^{\mathrm{c}}$ & $1.31^{\mathrm{bc}}$ & $0.10^{*}$ \\
$\left(\mathrm{~g} \mathrm{~cm}^{-3}\right)$ & 2 & 1.37 & 1.33 & 1.32 & 1.30 & 1.31 & 1.30 & $\mathrm{~ns}$ \\
Aggregate stability $^{\%}$ & 1 & $51.61^{\mathrm{b}}$ & $51.18^{\mathrm{b}}$ & $51.87^{\mathrm{b}}$ & $52.05^{\mathrm{b}}$ & $56.56^{\mathrm{a}}$ & $57.02^{\mathrm{a}}$ & $3.22^{* *}$ \\
$(\%)$ & 2 & $52.27^{\mathrm{b}}$ & $53.49^{\mathrm{b}}$ & $53.34^{\mathrm{b}}$ & $58.07^{\mathrm{a}}$ & $60.88^{\mathrm{a}}$ & $60.22^{\mathrm{a}}$ & $3.25^{* *}$ \\
Hydraulic conductivity $_{\left(\mathrm{cm} \mathrm{h}^{-1}\right)}$ & 1 & $0.64^{\mathrm{b}}$ & $0.90^{\mathrm{b}}$ & $1.45^{\mathrm{ab}}$ & $2.07^{\mathrm{ab}}$ & $2.88^{\mathrm{a}}$ & $2.92^{\mathrm{a}}$ & $1.54^{*}$ \\
\hline
\end{tabular}

: Means with the same letter for each parameter are significantly different $(\mathrm{P}=0.05),{ }^{* *}:$ Means with the same letter for each parameter are significantly different $(\mathrm{P}=0.01)$, ns: not significant

Present findings revealed that MSWC treatments significantly increased saturated hydraulic conductivity (Ksat) of the soils in both years $(\mathrm{P} \leq 0.05$ in the first year; $\mathrm{P} \leq 0.01$ in the second year). The greatest increase was observed in $200 \mathrm{t} \mathrm{ha}^{-1}$ compost treatment of both years. The Ksat value of $0.88 \mathrm{~cm} \mathrm{~h}^{-1}$ in control treatment of the first year and $0.64 \mathrm{~cm} \mathrm{~h}^{-1}$ in the control treatment of the second year increased with $200 \mathrm{t} \mathrm{ha}^{-1}$ treatments respectively to $2.92 \mathrm{~cm} \mathrm{~h}^{-1}$ and $2.77 \mathrm{~cm} \mathrm{~h}^{-1}$ (Table 4). It was reported that MSWC treatments increased Ksat especially of clay soils (Yuksel, 2012; Hamidpour, 2012). Mylavarapu and Zinati (2009) experimented various organic amendments and fertilizers and reported the greatest effects on Ksat for compost treatments. Positive impacts of MSWC on Ksat were attributed to high OM contents of MSWC (Zamani et al., 2016). MSWC with high OM contents provided better soil aggregation (Hemmat et al., 2010), increased macropore quantities (Yazdanpanah, 2016), thus increased Ksat.

\section{Conclusions}

MSWC treatments had significant effects on soil chemical characteristics (OM, EC, CEC) and physical characteristics (AS, BD and Ksat). Field experiments were conducted in this study with single MSWC treatments. Soil OM contents increased about 3 folds with MSWC treatments. Parallel to increasing OM contents, CEC values also increased and such an increase was about $25 \%$ in 200 $\mathrm{t}$ ha $^{-1}$ MSWC dose as compared to the control treatments. MSWC treatments did not have significant effects on soil $\mathrm{pH}$ values. Since experimental soils were slightly alkaline, MSWC treatments did not influence soil $\mathrm{pH}$ values.

Together with increasing OM contents, AS and Ksat values of the soils also increased and BD values decreased. MSWC increases soil OM contents and accordingly soil humic acid contents, thus regulates soil aggregation. In this way, soil macropores increases, BD decreases and Ksat increases. All these parameters are interdependent parameters. Correlation analyses revealed significant $(\mathrm{P} \leq 0.01)$ relationships between soil OM content and AS in both years $(\mathrm{r}=0.783 * *$ in the first year; $\mathrm{r}=0.862 * *$ in the second year).

Present MSWC has high salt contents and thus significantly increased soil salt contents. Such increases were high especially in the first year in which compost treatments were applied, thus the increase in salt contents was found to be significant in the first year at $1 \%$ level. However even at the highest rate $\left(200 \mathrm{t} \mathrm{ha}^{-1}\right)$ of compost applications, soil is still classified as non-saline. Although the salt contents decreased in the second year without compost treatments through the leaching, attention should be paid while applying MSWC in arid and semi-arid regions especially with drainage problems. MSWC should not be applied every year to avoid soil salinization.

It was concluded based on present findings that single MSWC treatments had positive impacts on soil physical and chemical characteristics (except for $\mathrm{pH}$ and salt content). Regular MSWC applications may sustain such positive impacts on soil properties.

\section{Acknowledgements}

This study was supported by Canakkale Onsekiz Mart University with BAP-2002/25 project number.

\section{References}

Albiach R, Canet, R, Pomares, F, Ingelmo, F. 2001. Organic matter components and aggregate stability after the application of different amendments to a horticultural soil. Bioresource Technology, 76 (2): 125-129.

Alvarenga P, Mourinha C, Farto M, Santos T, Palma P, Sengo J, Morais MC, Cunha-Queda C. 2015. Sewage sludge, compost and other representative organic wastes as agricultural soil amendments: benefits versus limiting factors. Waste Management, 40: 44-52.

Amlinger F, Peyr S, Geszit J, Dreher P, Weinfurtner K, Nortcliff S. 2007. Beneficial Effects of Compost Application on Fertility and Productivity of Soils: A Literature Study. Federal Ministry for Agriculture and Forestry, Environment and Water Management, Vienna, Austria.

Annabi M, Houot S, Francou C, Poitrenaud M, Bissonnais YL. 2007. Soil aggregate stability improvement with urban composts of different maturities. Soil Sci.Soc. Amer. J., 71: 413-423.

Atagana IH, Haynes RJ, Wallis FM. 2003. Co-Composting of Soil Heavily Contaminated with Creosote with Cattle Manure and Vegetable Waste for the Bioremediation of CreosoteContaminated Soil. Soil and Sediment Contamination, 12: 885-899.

Bastida F, Moreno JL, Garcia C, Hernández T. 2007. Addition of urban waste to semiarid degraded soil: long-term effect. Pedosphere, 17(5): 557-567.

Blake GR, Hartge KH. 1986. Bulk Density, (Ed: Klute, A.), Methods of Soil Analysis, Part 1. Physical and Mineralogical Methods. Soil Science Society of America, Madison, p. 363375 .

Carbonell G, De Imperial RM, Torrijos M, Delgado M, Rodriguez JA. 2011. Effects of municipal solid waste compost and mineral fertilizer amendments on soil properties and heavy metals distribution in maize plants (Zea mays L.). Chemosphere, 85: 1614-1623. 
Civeira G. 2010. Influence of municipal solid waste compost on soil properties and plant reestablishment in Peri-Urban environments. Chilean J. Agricultural Research, 70 (3): 447 453.

Crecchio C, Curci M, Mininni R, Ricciuti P, Ruggiero P. 2001. Short-term effects of municipal solid waste compost amendments on soil carbon and nitrogen content, some enzyme activities and genetic diversity. Biology and Fertility of Soils, 34: 311-318.

Diacono M, Montemurro F. 2010. Long-term effects of organic amendments on soil fertility. A review. Agronomy for sustainable development, 30 (2): 401-422.

EAWAG 1970. Methoden zur Untersuchung Von Abfallstoffen Abteilung für Müllforschung, Schweiz-8600, Düberdorf.

Eibisch N, Durner W, Bechtold M, Fuß R, Mikutta R, Woche SK, Helfrich M. 2015. Does water repellency of pyrochars and hydrochars counter their positive effects on soil hydraulic properties?. Geoderma, 245: 31-39.

Erhart E, Hartl W. 2010. Compost use in organic farming, (Ed: Lichtfouse E.), Genetic Engineering, Biofertilisation, Soil Quality and Organic Farming. Springer, Netherlands. p. 311345.

Füleky G, Benedek S. 2010. Composting to recycle biowaste, (Ed: Lichtfouse, E.), Sociology, Organic Farming, Climate Change and Soil Science, Springer, Netherlands, p. 319-346.

Gallardo-Lara F, Nogales R. 1987. Effect of the application of town refuse compost on the soil-plant system: a review. Biological Wastes, 19: 35-62.

Gee GW, Bauder JW. 1986. Particle-size analysis, (Ed: Klute A.), Methods of soil analysis. Part I: Physical and mineralogical methods. Am. Soc. Agronomy, Madison, p. 383-412.

Hamidpour M, Afyuni M, Khadivi E, Zorpas A, Inglezakis V. 2012. Composted municipal waste effect on chosen properties of calcareous soil. Int. Agrophysics, 26: 365-374.

Hargreaves JC, Adl MS, Warman PR. 2008. A review of the use of composted municipal solid waste in agriculture. Agr. Ecosyst. Environment, 123: 1-14.

Hemmat A, Aghilinategh N, Rezainejad Y, Sadeghi M. 2010. Long-term impacts of municipal solid waste compost, sewage sludge and farmyard manure application on organic carbon, bulk density and consistency limits of a calcareous soil in central Iran. Soil and Tillage Research, 108 (1): 43-50.

Hicklenton PR, Rodd V, Warman PR. 2001. The effectiveness and consistency of source-separated municipal solid waste and bark composts as components of container growing media. Sci. Hortic., 91: 365-378.

ISTAC 2018. Evaluation of Organic Wastes. http://www.istac.istanbul/en/clean-istanbul/domesticwastes/regaining-compost (accessed 25.06.2017).

Karami A, Homaee M, Afzalinia S, Ruhipour H, Basirat S. 2012. Organic resource management: impacts on soil aggregate stability and other soil physico-chemical properties. Agric. Ecosyst. Environ., 148: 22-28.

Kavdir Y, Ilay R, Camci Cetin S, Buyukcan MB, Kavdir I. 2020. Monitoring composting process of olive oil solid waste using FT-NIR spectroscopy. Communications in Soil Science and Plant Analysis, 1-13.

Kavdır Y, Killi D. 2008. Influence of olive oil solid waste applications on soil $\mathrm{pH}$, electrical conductivity, soil nitrogen transformations, carbon content and aggregate stability. Bioresource Technology, 99: 2326-2332.

Kemper WD, Rosenau RC. 1986. Aggregate stability and size distribution, (Ed: Klute, A.), Methods of Soil Analysis, Part 1-Physical and Mineralogical Methods. SSSA, Madison, p. 425-442.

Klute A, Dirksen C. 1996. Hydraulic Conductivity and Diffusivity: Laboratory Methods, (Ed: Klute A.), Methods of Soil Analysis, Part 1-Physical and Mineralogical Methods. SSSA, Madison, Wisconsin, p. 687-734.
Leroy BLM, Herath HMSK, Sleutel S, De Neve S, Gabriels D, Reheul D, Moens M. 2008. The quality of exogenous organic matter: short-term effects on soil physical properties and soil organic matter fractions. Soil Use and Management, 24: 139147.

Loeppert RH, Suarez DL. 1996. Carbonate and Gypsum, (Ed: Sparks, DL.), Methods of Soil Analysis, Part 3-Chemical Methods, SSSA, Madison, Wisconsin, p. 437-474.

Loveland P, Webb J. 2003. Is there a critical level of organic matter in the agricultural soils of temperate regions: a review. Soil and Tillage Research, 70 (1): 1-18.

Mylavarapu RS, Zinati GM. 2009. Improvement of soil properties using compost for optimum parsley production in sandy soils. Scientia Horticulturae, 120 (3): 426-430.

Nelson DW, Sommers LE. 1996. Total Carbon, Organic Carbon, and Organic Matter, (Ed: Sparks, DL.), Methods of Soil Analysis, Part 3-Chemical Methods. SSSA, Madison, Wisconsin, p. 961-1010.

Neves L, Ferreira V, Oliveira R. 2009. Co-composting cow manure with food waste: The influence of lipids content. World Academy of Science, Engineering and Technology, 34: 986-991.

Ozcan H, Ekinci H, Yuksel O, Kavdir Y, Kaptan H. 2004. Dardonos Yerleşkesi Toprakları. ÇOMU Ziraat Fakultesi, Canakkale.

Pedra F, Polo A, Ribeiro A, Domingues H. 2007. Effects of municipal solid waste compost and sewage sludge on mineralization of soil organic matter. Soil Biol. Biochemistry, 39: $1375-1382$.

Piccolo A, Zaccheo P, Genevini PG. 1992. Chemical characterization of humic substances extracted from organicwaste-amended soils. Bioresource Technology, 40 (3): 275282.

Sanchez A, Gabarrell X, Artola A, Barrena R, Colon J, Font X, Komilis D. 2016. Composting of Wastes, (Eds: Taherzadeh MJ, Richards T.), Resource Recovery to Approach Zero Municipal Waste. CRC Press, Boca Raton (FL), p. 77-116.

Soil Survey Staff. 1996. Keys to soil taxonomy, 7th ed. U.S. Gov. Print. Office, Washington, DC.

Steel RGD, Torrie JH. 1960. Principles and Procedures of Statistics with Special Reference to the Biological Approach. McGraw-Hill, New York.

Sumner ME, Miller WP. 1996. Cation Exchange Capacity and Exchange Coefficients, (Ed: Sparks, DL.), Methods of Soil Analysis, Part 3-Chemical Methods, SSSA, Madison, Wisconsin, p. 1201-1229.

Sutherland RA. 1998. Loss-on-ignition estimates of organic matter and relationships to organic carbon in fluvial bed sediments. Hydrobiologia, 389 (1): 153-167.

Tejada M, Gonzalez JL. 2007. Influence of organic amendments on soil structure and soil loss under simulated rain. Soil and Tillage Research, 93 (1): 197-205.

TUIK. 2017. Turkish Statistical Institute, Statistics of Waste Disposal and Recovery Facilities 2016. Ankara, Turkey. http://www.tuik.gov.tr/PreHaberBultenleri.do?id=24877 (accessed 16.06.2018).

Weber J, Karczewska A, Drozd J, Licznar M, Licznar S, Jamroz E. 2007. Agricultural and ecological aspects of a sandy soil as affected by the application of municipal solid waste composts, Soil Biology and Biochemistry, 39: 1294-1302.

Weber J, Kocowicz A, Bekier J, Jamroz E, Tyszka R, Debicka M, Parylak D, Kordas L. 2014. The effect of a sandy soil amendment with municipal solid waste (MSW) compost on nitrogen uptake efficiency by plants. Eur J Agron., 54: 54-60

Westerman PW, Bicudo JR. 2005. Management considerations for organic wastes use in agriculture. Bioresource Technology, 96: 215-221.

Yazdanpanah N, Mahmoodabadi M, Cerdà A. 2016. The impact of organic amendments on soil hydrology, structure and microbial respiration in semiarid lands. Geoderma, 266: 58-65. 
Yuksel O, Kavdir Y, Bahtiyar M. 2004. The effect of municipal waste compost on physical characteristics of clay soils Fresenius Environmental Bulletin, 13 (11): 1094-1098.

Yuksel O, Turhan H, Kavdir Y. 2011. Çanakkale koşullarında çöp kompostunun ayçiçeği tarımında kullanılması. Çanakkale Tarımı Sempozyumu (Dünü, Bugünü ve Geleceği). ÇOMÜ. Ziraat Fakültesi, Çanakkale, Turkey, p. 453-45 (in Turkish)

Yuksel O. 2012. Effect of Waste Compost on Physical Properties in Xerofluvent Soils. Journal of Tekirdag Agricultural Faculty, 9(2): 92-97.

Yuksel O. 2015. Influence of municipal solid waste compost application on heavy metal content in soil, Environmental Monitoring and Assessment, 187:313-320
Zamani J, Afyuni M, Sepehrnia N, Schulin R. 2016. Opposite effects of two organic wastes on the physical quality of an agricultural soil. Archives of Agronomy and Soil Science, 62(3): 413-427.

Zhang M, Heaney D, Henriquez B, Solberg E, Bittner E. 2006. A Four-Year Study on Influence of Biosolids/MSW Cocompost Application in Less Productive Soils in Alberta: Nutrient Dynamics. Compost Science and Utilization, 14: 68-80.

Zheljazkov V, Warman PR. 2004. Source-separated municipal soil waste compost application to Swiss chard and basil. J. Environ. Qual., 33: 542-552. 